\title{
Evaluation of Dynamic Mechanical Properties of Fique Fabric/Epoxy Composites
}

\author{
Michelle Souza Oliveira ${ }^{a} \oplus$, Fabio da Costa Garcia Filho ${ }^{a} \oplus$, Fernanda Santos da Luz ${ }^{a} \oplus$, \\ Luana Cristyne da Cruz Demosthenes ${ }^{a} \oplus$, Artur Camposo Pereira ${ }^{a}{ }^{\oplus}$, Henry Alonso Colorado ${ }^{b}$, \\ Lucio Fabio Cassiano Nascimento ${ }^{a} \oplus$, Sergio Neves Monteiro ${ }^{a}{ }^{\oplus}$ \\ a Departamento de Ciência dos Materiais, Instituto Militar de Engenharia, Rio de Janeiro, RJ, Brasil. \\ ${ }^{b}$ Facultad de Ingeniería, Universidad de Antioquia, Medellin, Colombia.
}

Received: February 11, 2019; Revised: July 10, 2019; Accepted: August 15, 2019.

\begin{abstract}
The fique is a plant typical of the Colombian Andes, from which relatively common items are fabricated. One of these is woven fabric extensively applied in sackcloths. The mechanical strength of fique fabric have motivated recent investigations on possible reinforcement of polymer matrix composites. For this purpose its thermo-mechanical behavior was unveiled. In particular, dynamic mechanical analysis (DMA) of fique fabric reinforced polyester matrix composites disclosed improved viscoelastic behavior in association with change in the glass transition temperature. The present work extends this investigation to epoxy matrix, which is one of the most employed thermoset polymer for composite matrix. Fique fabric volumetric fractions of up to $50 \%$ are for the first time incorporated into epoxy composites. It was found that these incorporations significantly increased the viscoelastic stiffness of the composite, given by the storage modulus (E'), in the temperature interval from -50 to $170^{\circ} \mathrm{C}$. An accentuated softening in viscoelastic stiffness was revealed for all composites above $75^{\circ} \mathrm{C}$. Peaks in both the loss modulus (E”) and tangent delta (tan $\delta$ ), respectively associated with the lower and upper limits of the glass transition temperature, were shifted towards higher temperatures with increasing amount of fique fabric.
\end{abstract}

Keywords: Fique fabric, epoxy matrix, natural fiber composite, dynamic mechanical analysis.

\section{Introduction}

The environment in modern society is facing depletion of natural resources in association with increasing demand of energy and generation of wastes. This worrisome situation is motivating actions involving more efficient use of materials combined with sustainable saving in energy and recycling of wastes. An example of efficient use of materials is the development of micro and nanoparticles composites with improved mechanical properties ${ }^{1,2}$. A relevant action is the substitution of synthetic fiber for natural renewable ones, for instance, lignocellulosic fibers. In this respect, lignocellulosic fibers extracted from plants are prominent examples $^{3,4}$. These fibers, used by humankind from primeval times are, since the beginning of this century, replacing synthetics fibers in technological applications, specially as reinforcement of polymer composites ${ }^{4-9}$. The remarkable growth in the use of these composites is shown in Fig 1 from ISI Web of Science databases, which projects about 2,000 papers published at the beginning of the next decade highlighting the keywords "natural fiber composites". Indeed, many review and original articles ${ }^{10-27}$ emphasized, throughout this decade, the interesting properties of polymer composites reinforced with numerous natural fibers and corresponding fabrics.

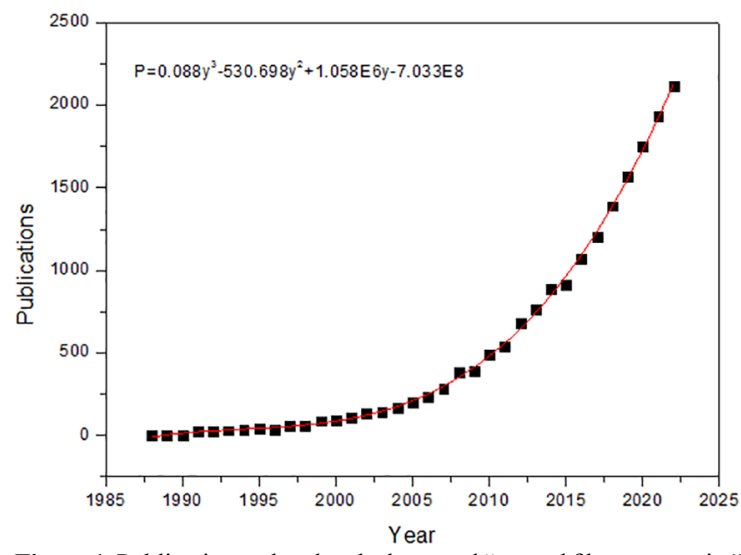

Figure 1. Publications related to the keyword "natural fiber composite" generated by the ISI Web of Science database.

Less known natural fibers, not mentioned in reviews, still require research work for possible application as composite reinforcement. For instance, the fique fiber, which is extracted from the leaves of Furcraea andina, a widespread plant in the Colombian Andes, South America. Woven fabric made with fique fiber is commonly found in Colombia as sackcloth to transport and store agricultural products. Figure 2 illustrate the fique plant as well as extracted fibers and weaved fabric.

*e-mail: oliveirasmichelle@gmail.com 


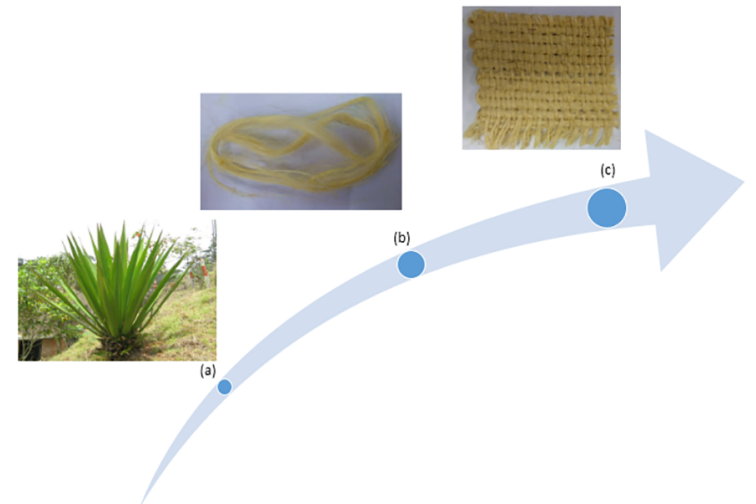

Figure 2. (a) Plant of fique (Furcraea andina), (b) fique fibers, and (c) fique fabric.

Considering the superior properties of fique fiber, such as strength and stifness, when compared with other common natural fibers, this fiber have been brought to attention as potential reinforcement for composites, either in the form of filament ${ }^{28-33}$ or even in the form of fabric ${ }^{34-35}$. In particular the thermal and mechanical properties, important for engineering applications involving change in temperature conditions, were recently studied for fique fabric polyester composites by dynamic mechanical analysis (DMA) ${ }^{34}$. It was found that the incorporation of up to $30 \mathrm{vol} \%$ of fique fabric is associated with a viscoelastic stiffness of about $1400 \mathrm{MPa}$ for its polyester composite. A sudden drop in the value of storage modulus (E'), around $30-40^{\circ} \mathrm{C}$, indicated the onset of glass transition $\left(\mathrm{T}_{\mathrm{g}}\right)$. The maximum in the tangent delta $(\tan \delta)$, i.e. the ratio between loss and storage modulus (E"/E'), suffers not only a reduction in amplitude but also a shift towards temperatures slightly above $70^{\circ} \mathrm{C}$, corresponding to the upper limit of $\mathrm{T}_{\mathrm{g}}$.

Epoxy is another thermosetting polymer commonly used as engineering composite matrix. Therefore, the present work investigated for both scientific and practical purpose the DMA behavior of epoxy matrix composites reinforced with fique fabric. As a comparison with reported results on polyester composites ${ }^{34}$ and expansion to higher amounts, this work investigated not only 15 and $30 \mathrm{vol} \%$ but also higher amounts of 40 and $50 \mathrm{vol} \%$ of fique fabric incorporation into epoxy composites.

\section{Materials and Methods}

The fique fabric was purchased from a local supplier in the city of Antioquia, Colombia. Pieces of fabric, like the one illustrated in Fig. 2(c), were cut in convenient dimensions for DMA specimen preparation. The as-cut pieces of fique fabric were cleaned in running water and dried in stove at $60^{\circ} \mathrm{C}$ for one day. As composite matrix, a type diglycidyl ether of the bisphenol-A (DGEBA) epoxy resin and triethylene tetramine (TETA) hardener from Dow Chemical, were supplied by Epoxyfiber, Brazil.
Composites were fabricated by placing the previously dried fabric pieces as layers inside a steel mold. DGEBA resin and TETA hardener mixed in stoichiometric proportion of $\mathrm{phr}=13$ was poured in between fabric layers. Laminate plates with $120 \times 150 \times 10 \mathrm{~mm}$, respectively length, width and thickness, were manufactured incorporating 15, 30, 40 and $50 \mathrm{vol} \%$ of fique fabric, corresponding to $1,2,3$ and 4 layers, respectively. To avoid epoxy spilling off the mold, its lid was closed and pressure was applied after 24 to 27 minutes when the resin reached its gel point visually identified by turning to a milky aspect. The plate was then kept under pressure of $3 \mathrm{MPa}$ for $24 \mathrm{~h}$ at room temperature $\left(\sim 25^{\circ} \mathrm{C}\right)$ until complete solid cure. This procedure guaranteed the precise volume fraction of epoxy to be maintained in the composite plate, which was further certified by measuring its density using the Archimedes method. After cure the composite laminate plates were cut along the length in smaller $13 \times 50 \times 5 \mathrm{~mm}$ specimens, with their thickness direction along the plate width. DMA tests were conducted in a model Q 800 TA Instruments using the three-points flexural mode. The test operational conditions were a frequency of $1 \mathrm{~Hz}$, nitrogen atmosphere and heating rate of $3^{\circ} \mathrm{C} / \mathrm{min}$. Curves of E', E' and $\tan \delta$ variation with temperature were simultaneously recorded between -50 and $170{ }^{\circ} \mathrm{C}$ for specimens with distinct volume fractions of fique fabric.

\section{Results and Discussion}

Figure 3 shows a typical set of DMA curves (E', E', and $\tan \delta$ ) for the fique fabric/epoxy composite with $50 \mathrm{vol} \%$ of fique fabric. The characteristic shape of each curve is compared in this figure. For instance, the storage modulus (E'), associated with viscoelastic stiffness, tends to continuously decrease with temperature and displays a transition around $70-80^{\circ} \mathrm{C}$. This transition to a steeper decrease in temperature can be related to a softening process in viscoelasticity, which might be assigned to a less rigid internal molecular structure ${ }^{36}$.

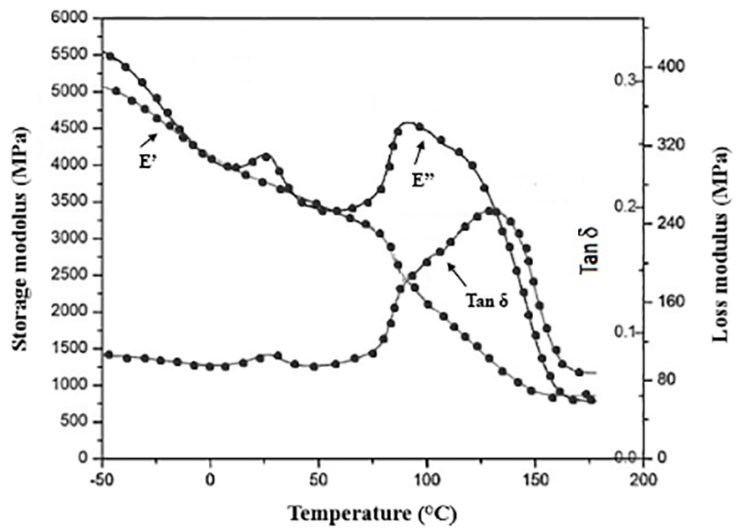

Figure 3. Variation of the dynamic-mechanical parameters with the temperature for the composite with $50 \mathrm{vol} \%$ of fique fabric. 
The gradual loss in the molecular 3D arrangement of the polymer matrix, i.e. the transition from crystalline to amorphous or glass structure, is a possible reason for the steeper decrease in E'. Another noticeable effect of this transition in Fig. 3 is the main peak in the curve of E" with temperature. Indeed, the loss modulus is often associated with internal friction and is sensitive to molecular motion ${ }^{36}$. Mohanty et al..$^{37}$ indicated that the maximum value in $E$ " is the relaxation alpha $(\alpha)$ peak attributed to the mobility of the polymer chains in going from crystalline to amorphous molecular structure. They suggested that the a peak could be associated with the onset of the glass transition temperature $\left(\mathrm{T}_{\mathrm{g}}\right)$ of the polymeric matrix. As one may notice in Fig. 3, the beginning of steeper decrease in the temperature for E' happens at about the same value of the E' a peak. The $\tan \delta$ in Fig. 3 also display a characteristic peak, shifted towards higher temperatures in comparison with the E" peak, and related to the damping capacity of the material. According to Saba et al. ${ }^{36}$, a high $\tan \delta$ value is indicative of a material having non-elastic strain component, while a low value indicates high elasticity. Since the damping factor is related to molecular movements, the $\tan \delta$ peak might be interpreted as the upper value of $\mathrm{T}_{\mathrm{g}}$. As shown in Fig. 3, these peaks occur shortly in temperature, around $120-130^{\circ} \mathrm{C}$, at the end of the steeper decrease in $\mathrm{E}^{\prime}$.

As the main objective of this work being the effect of fique fabric incorporation into epoxy matrix, Fig. 4 shows the variation of E' with temperature for the different investigated composites. In this figure it is important to notice the significant increase in the value of $\mathrm{E}$ ' with the volume fraction of fique fabric, especially from the initial interval of temperature at $-50^{\circ} \mathrm{C}$ up to the end of steeper decrease at about $100-150^{\circ} \mathrm{C}$.

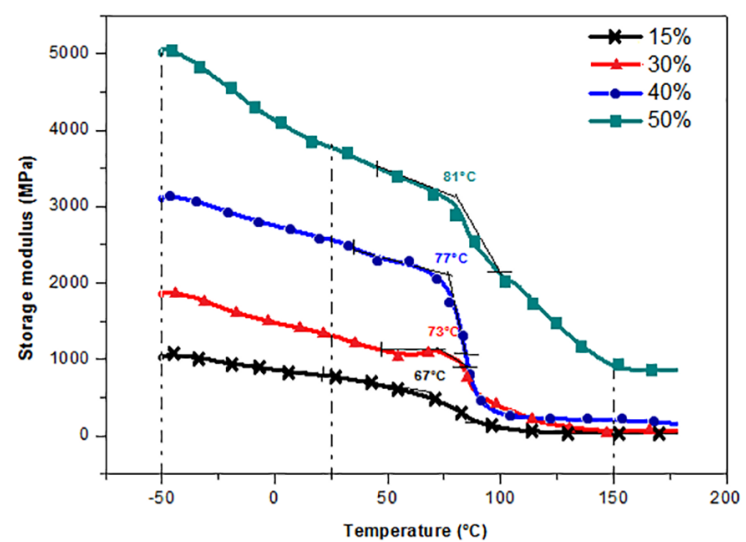

Figure 4. Variation of the storage modulus, $E^{\prime}$, with the temperature for the fique fabric composites.
Table 1 presents values of storage modulus at different levels of temperature for the epoxy matrix composites incorporated with different volume fractions of fique fabric, based on the $\mathrm{E}$ ' curves, shown in Fig. 4. At any temperature level in this table, the value of $\mathrm{E}^{\prime}$ is higher with increasing volume fraction. In particular, at $-50^{\circ} \mathrm{C}$ the value of E' reaches $5,000 \mathrm{MPa}$, which is among the highest attained for natural fabric reinforced polymer composites. At $25^{\circ} \mathrm{C}$, a comparison with $30 \mathrm{vol} \%$ fique fabric polyester composite, with E' equal to $1,300 \mathrm{MPa}^{34}$, revealed a close value of $1250 \mathrm{MPa}$ for the same amount of $30 \mathrm{vol} \%$ fique fabric epoxy composite in Table 1. As for the transition to steeper decrease in temperature, which might be consider a lower $\mathrm{T}_{\mathrm{g}}$ limit, Table 1 reveals a slight increase, 67 to $81^{\circ} \mathrm{C}$, with volume fraction of fique fabric. These values are marked higher than those of fique fabric polyester composites, 32 to $43^{\circ} \mathrm{C}^{34}$. In either case, epoxy or polyester matrix, the incorporation of fique fabric displaces the beginning of glass transition to higher temperatures. This is apparently a consequence of fique fabric interference in the mobility of polymer chains. The end of the steeper decrease occurs at about $100^{\circ} \mathrm{C}$ for the 15,30 and $40 \mathrm{vol} \%$, but only at $150^{\circ} \mathrm{C}$ for the $50 \mathrm{vol} \%$ fique fabric epoxy composite in Fig. 4. These are sensibly higher temperatures for complete viscoelastic softening as compared to about $80^{\circ} \mathrm{C}$ for the 10,20 and $30 \mathrm{vol} \%$ fique fabric polyester composites ${ }^{34}$. These results can only be attributed to differences in the polymer matrices and suggest that, as matrix for fique fabric, the epoxy might be thermo-dynamically stiffer than polyester.

Figure 5 shows the variation of E" with temperature for the different investigated composites. For all volume fractions of incorporated fique fabric the loss modulus

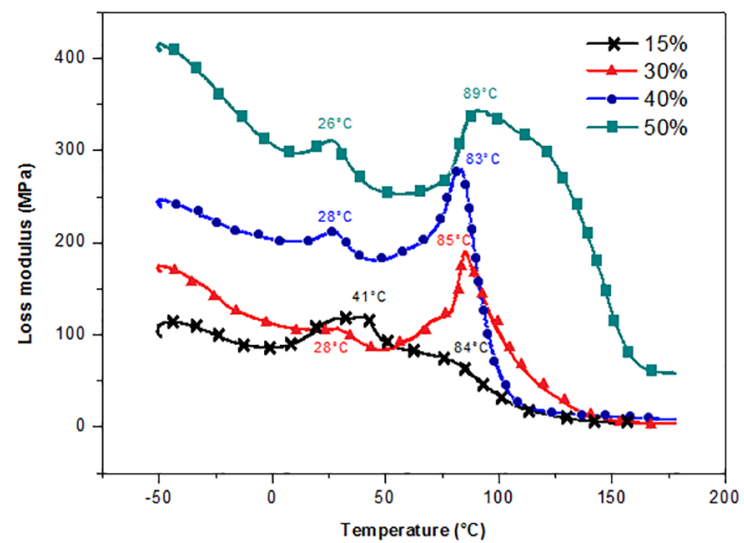

Figure 5. Variation of loss modulus, E", as a function of temperature for the different fique fabric composites.

Table 1. Storage modulus temperature-related parameters for epoxy composites reinforced with fique fabric

\begin{tabular}{ccccc}
\hline Epoxy composite reinforced fique fabric (vol\%) & \multicolumn{3}{c}{ Storage modulus (MPa) } \\
\cline { 2 - 5 } & $-50^{\circ} \mathrm{C}$ & $25^{\circ} \mathrm{C}$ & Steeper decrease transition $\left({ }^{\circ} \mathrm{C}\right)$ & $150^{\circ} \mathrm{C}$ \\
\hline 15 & 1043 & 767 & 516 & 7 \\
30 & 1845 & 1319 & 1090 & 65 \\
40 & 3149 & 2577 & 1868 & 219 \\
50 & 5073 & 3790 & 3081 & 906 \\
\hline
\end{tabular}


displays, consistently, small first peak around $28-41^{\circ} \mathrm{C}$. Peaks such as these are not found in the literature for plain polymers such as polyester ${ }^{34}$ or high density polyethylene ${ }^{37}$. It is suggested that these small peaks might be related to some feature inherent to the fique fabric, which must be further investigated. The main results in Fig. 5 are the a peaks observed around 83$89^{\circ} \mathrm{C}$. Relevant points are worth discussing with regard to these a peaks. First, they occur at temperatures significantly higher than those, $28-51{ }^{\circ} \mathrm{C}$, for fique fabric in polyester composites $^{34}$. This could also be associated with the difference in resistance to loose crystallinity between the two polymers. The epoxy would begin its amorphous or glass transition at relatively higher temperatures. Second, the maximum a peak in Fig. 5 corresponds to the $50 \mathrm{vol} \%$ fique fabric epoxy composite with E" approximately $350 \mathrm{MPa}$ at the highest temperature of $89^{\circ} \mathrm{C}$. According to Lopez-Machado et $\mathrm{al}^{38}$, the presence of natural fiber reduces the flexibility of the matrix by introducing constraints on the segmental mobility of polymer molecules at the relaxation temperature. For the $30 \mathrm{vol} \%$ fique fabric composites, both with epoxy and polyester ${ }^{34}$ matrices, the values of E", approximately 200 $\mathrm{MPa}$, are practically the same. A surprising situation was found for $15 \mathrm{vol} \%$ fique fabric epoxy composite in Fig. 5, which displays an almost nonexistent a peak at $84^{\circ} \mathrm{C}$. This must also be further investigated.

Figure 6 shows the variation of $\tan \delta$ with temperature for the different investigated composites. In this figure, the expected effect of fique fabric addition is confirmed. As in the case of polyester composites ${ }^{34}$, the increase in volume fraction tends to decrease the amplitude of the peaks that are also shifted to relatively higher temperatures. Ray et $\mathrm{al}^{39}$ indicated that the incorporation of fibers restricts the mobility of the polymer molecules, raising the E', which is observed in Fig. 4 for the fique fabric. Further, it reduces the viscoelastic lag between the stress and the strain. Hence, tan $\delta$ values in Fig. 6 are decreases in the composite. The $\tan \delta$ values were also lowered with increasing volume fraction of

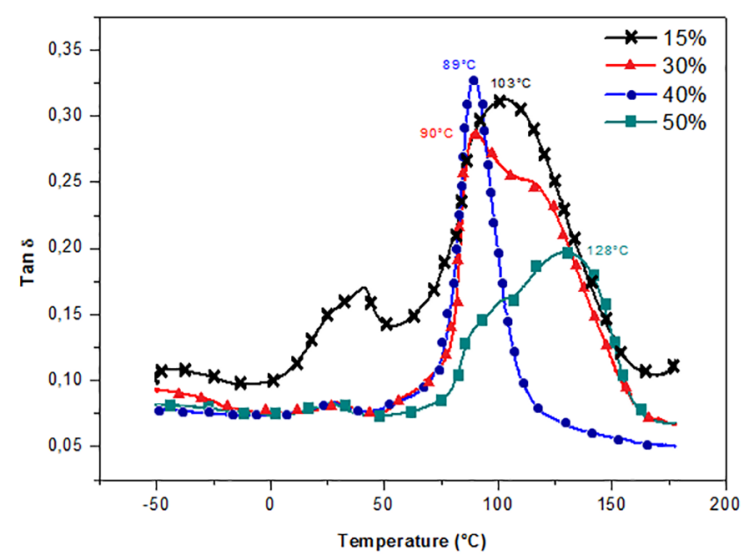

Figure 6. Variation of Tan $\delta$ with temperature for reinforced epoxy composites with different volumetric fractions of fique fabric. fique fabric in Fig. 6 because there was less epoxy volume to dissipate the vibrational energy.

The results in Figures 4 to 6 clearly shows that the introduction of fique fabric in epoxy matrix tends to shift both the lower and the upper limit of $\mathrm{T}_{\mathrm{g}}$ to higher temperatures. This retards the softening of the composite, which might be interpreted as a difficult of the thermoset polymer matrix to change its molecular arrangement from a "glassy" rigid or hard state to a more compliant, pliable or "rubbery" $\mathrm{state}^{36}$.

\section{Conclusions}

- The introduction of fique fabric as reinforcement in epoxy matrix composites raised the viscoelastic stiffness and consistently shifted the transition of the steeper decrease in storage modulus (E') to higher temperatures. This leads to a delay in the onset of the composite thermal softening, which might be considered a lower limit for the crystalline transition to amorphous structure.

- The value of E' equal to $5073 \mathrm{MPa}$ for the $50 \mathrm{vol} \%$ fique fabric epoxy composite is amongst the highest for natural fabrics reinforced polymer composites. Such elevate volume fraction of fique fabric has not been investigated in a previous work with polyester matrix composites.

- The a peak, maximum in the loss modulus (E") curve and generally assigned to the glass transition temperature, $\mathrm{T}_{\mathrm{g}}$, tends to be slightly shifted to higher temperatures, $83-89^{\circ} \mathrm{C}$. When compared to corresponding ones reported for polyester composites, $28-52^{\circ} \mathrm{C}$, these E" a peaks are sensibly higher in fique fabric epoxy composites. This indicates less mobility in epoxy chains by interaction with fique fabric.

- The maximum values associated with peaks in tan $\delta$ curves, which are a consequence of damping in vibrational energy of the macromolecular polymer structure, might be an upper limit for the crystalline transition towards a full amorphous structure. As in any natural fiber composites, especially the recently investigated fique fabric in polyester matrix, the increase in volume fraction tends to decrease the amplitude of the $\tan \delta$ peak. In principle, this could be due to less epoxy volume to dissipate the vibrational energy.

\section{Acknowledgements}

The authors thank the support to this investigation by the Brazilian agencies: CNPq, FAPERJ and CAPES.

\section{References}

1. Nezhad HY, Thakur VK. Effect of morphological changes due to increasing carbon nanoparticles content on the quasi-static mechanical of epoxy resin. Polymers (Basel). 2018;10(10):pii:E1106. 
2. Pappu A, Thakur VK. Towards sustainable micro and nano composites from fly ash and natural fibers for multifunctional applications. Vacuum. 2017;146:375-385.

3. Monteiro SN, Lopes FPD, Ferreira AS, Nascimento DCO. Natural fiber polymer-matrix composites: Cheaper, tougher and environmentally friendly. JOM Journal of the Minerals Metals \& Materials Society. 2009;61(1):17-22.

4. Singha AS, Thakur VK. Saccaharum cilliare fiber reinforced polymer composites. E-Journal of Chemistry. 2008;5(4):782-791.

5. Marsh G. Next step automotive materials. Materials Today. 2003;6(4):36-43.

6. Holbery J, Houston D. Natural-fiber-reinforced polymer composites applications in automotive. JOM Journal of the Minerals Metals \& Materials Society. 2006;52(11):80-86.

7. Alves C, Ferrão PMC, Silva AJ, Reis LG, Freitas M, Rodrigues LB, Alves DE. Eco design of automotive components making use of natural jute fiber composites. Journal of Cleaner Production. 2010;18:313-327.

8. Thakur VK, Singha A. Mechanical and water absorption properties of natural fibers/polymer biocomposites. Polymer-Plastics Technology Engineering. 2010;49(7):694-700.

9. Krishna NH, Prasanth M, Gowtham R, Karthic S, Mini KM. Enhancement of properties of concrete using natural fibers. Materials Today: Proceedings. 2018;5(11 Pt 3):23816-23823.

10. John MJ, Thomas S. Biofibers and biocomposites. Carbohydrate Polymers. 2008;71:343-364.

11. Satyanarayana KG, Arizaga GGC, Wypych F. Biodegradable composites based on lignocellulosic fibers - An overview. Progress in Polymer Science. 2009;34(9):982-1021.

12. Summerscales J, Dissanayake N, Virk A, Hall W. A review of blast fibers and their composites. Part 1 - Fibers and reinforcement; Part 2 - Composites. Composites Part A: Applied Science and Manufacturing. 2010;41(10):1329-1335/1336-1344.

13. La-Mantia FP, Morreale M. Green composites: a brief review. Composites Part A: Applied Science and Manufacturing. 2011;42(6):579-588.

14. Zini E, Scendola M. Green Composites - An overview. Polymer Composites. 2011;32(12):1905-1915.

15. Ku H, Wang H, Pattarachayakoop N, Trada M. A review on tensile properties of natural fiber reinforced polymer composites. Composites Part B: Engineering. 2011;42(4):856-873.

16. Dittenber DB, Gangarao HVS. Critical review of recent publications on use of natural composites in infrastructure. Composites Part A: Applied Science and Manufacturing. 2012;43(8):1419-1429.

17. Faruk O, Bledzki AK, Fink HP, Sain M. Biocomposites reinforced with natural fibers: 2000-2010. Progress in Polymer Science. 2012;37:1552-1596.

18. Shah DU. Developing plant fiber composite for structural applications by optimizing composite parameters: A critical review. Journal of Materials Science. 2013;48(18):6083-6107.

19. Thakur VK, Thakur MK, Gupta RK. Review: Raw natural fiberbased polymer composites. International Journal of Polymer Analysis and Characterization. 2014;19(3):256-271.
20. Faruk O, Bledzki AK, Fink HP, Sain M. Progress report natural fiber reinforced composites. Macromolecular Materials and Engineering. 2014;299(1):9-26.

21. Pereira PHF, Rosa MF, Cioffi MOH, Benini KCCC, Milanese AC, Voorwald HJC, Mulinari DR. Vegetable fibers in polymeric composites: a review. Polímeros. 2015;25(1):9-22.

22. Saba N, Paridah MT, Jawaid M. Mechanical properties of kenaf fibre reinforced polymer composites: a review. Construction and Building Materials. 2015;76:87-96.

23. Mohammed L, Ansari MNM, Pua G, Jawaid M, Islam MS. A review on natural fiber reinforced polymer composites and its applications. International Journal of Polymer Science. 2015;2015:243947.

24. Güven O, Monteiro SN, Moura EAB, Drelich JW. Re-emerging field of lignocellulosic fiber-polymer composites and ionizing radiation technology in their formulation. Polymer Reviews. 2016;56(4):702-736.

25. Väisänen T, Haapala A, Lappalainen R, Tomppo L. Utilization of agricultural and forest industry waste and residues in natural fiberpolymer composites: Areview. Waste Management. 2016;54:62-73.

26. Pickering KL, Efendy MGA, Le TM. A review of recent developments in natural fiber composites and their mechanical performance. Composites Part A: Applied Science and Manufacturing. 2016;83:98-112.

27. Sanjay MR, Madhu P, Jawaid M, Senthamaraikannan P, Senthil S, Pradeep S. Characterization and properties of natural fiber polymer composite: A comprehensive review. Journal of Cleaner Production. 2018;172:566-581.

28. Gañan P, Mondragon I. Surface modification of fiques. Effect on their physic-mechanical properties. Polymer Composites. 2002;23(3):383-394.

29. Gañan P, Mondragon I. Thermal and degradation behavior of fique fiber reinforced thermoplastic matrix composites. Journal of Thermal Analysis and Calorimetry. 2003;73(3):783-795.

30. Altoé GR, Netto PA, Barcelos M, Gomes A, Margem FM, Monteiro SN. Bending mechanical behavior of polyester matrix reinforced with fique fiber. In: Ikhmayies SJ, et al., eds. Characterization of Minerals, Metals and Materials. Hoboken, NJ, USA: John Wiley \& Sons, Inc.; 2015. p. 117-121.

31. Altoé GR, Netto PA, Teles MCS, Daniel G, Margem FM, Monteiro SN. Tensile strength of polyester composites reinforced with fique fibers. In: Ikhmayies SJ, et al., eds. Characterization of Minerals, Metals and Materials. Hoboken, NJ, USA: John Wiley \& Sons, Inc.; 2015. p. 465-470.

32. Altoé GR, Netto PA, Teles MCA, Borges LGX, Margem FM, Monteiro SN. Tensile strength of epoxy composites reinforced with fique fibers. In: Ikhmayies SJ, et al., eds. Characterization of Minerals, Metals and Materials. Hoboken, NJ, USA: John Wiley \& Sons, Inc.; 2016. p. 391-396.

33. Netto PA, Altoé GR, Margem FM, Braga FO, Monteiro SN, Margem IM. Correlation between the density and the diameter of fique fibers. Materials Science Forum. 2016;869:377-383. 
34. Monteiro SN, Assis FS, Ferreira CL, Simonassi NT, Weber RP, Oliveira MS, Colorado HA, Pereira AC. Fique fabric: a promising reinforcement for polymer composites. Polymers. 2018;10(3):246-254.

35. Teles MCA, Ferreira MVF, Margem FM, Lopes FPD, Souza D, Monteiro SN. Characterization of tensile properties of epoxy matrix composites reinforced with fique fabric. In: Lekhwani A, ed. The Minerals, Metals \& Materials Series. Switzerland: Springer International Publishing; 2018. p. 469-476.

36. Saba N, Jawaid M, Alothman OY, Paridah MT. A review on dynamic mechanical properties of natural fibre reinforced polymer composites. Construction and Building Materials. 2016;106:149-159.
37. Mohanty AK, Misra M, Hinrichen G. Biofibres, biodegradable polymers and biocomposites: An overview. Macromolecular Materials and Engineering. 2000;276-277(1):1-24.

38. Lopez-Machado MA, Biagitti J, Kenny JM. Comparative study of the effects of different fibres on the processing and properties of ternary composites based on PP-EPDM blends. Polymer Composites. 2002;23(5):779-789.

39. Ray D, Sarkar BK, Das S, Rana AK. Dynamic mechanical and thermal analysis of vinylester-resin-matrix composites reinforced with untreated and alkali-treated jute fibers. Composites Science and Technology. 2002;62(7-8):911-917. 